\title{
Follow the Money: Getting to the Root of the Problem with Civil Asset Forfeiture in California
}

\author{
Karis Ann-Yu Chi†
}

\section{INTRODUCTION}

"For the love of money is a root of all kinds of evil."

Financial gain is the obvious motive for many crimes. Ironically, this motive also explains the problematic behavior of law enforcement agencies involved in civil asset forfeiture. Civil asset forfeiture is a process by which the government seizes property suspected of having a connection to illegal drugs or other criminal activities and then remits the proceeds to the law enforcement agencies that participated in the seizure. ${ }^{2}$ This distribution scheme gives law enforcement agents, including police and prosecutors, a direct financial stake in civil asset forfeiture proceeds and creates a powerful incentive for law enforcement agencies to initiate and participate in forfeiture actions. ${ }^{3}$

Giving law enforcement agencies a financial interest in civil asset forfeiture is problematic because it may shift law enforcement objectives to maximizing forfeiture proceeds rather than deterring crime. ${ }^{4}$ For example, some police departments prefer arresting drug buyers rather than drug

Copyright 1002 California Law Review, Inc. California Law Review, Inc. (CLR) is a California nonprofit corporation. CLR and the authors are solely responsible for the content of their publications.

$+\quad$ J.D., School of Law, University of California, Berkeley (Boalt Hall), 2002; B.A., University of California, Los Angeles, 1998. I am grateful to God for my family, for their unceasing love, support, and encouragement throughout the years, with special thanks to my sister Tephillah, who has lived and stood with me through the best and the most tumultuous of times. My heartfelt gratitude is also extended to extraordinary friends from the Bruin Christian Fellowship, the California Assembly Fellowship Program, Boalt Hall, the Veritas Graduate Fellowship, and the Domingo House, for infusing my days with insight, humor, inspiration, and joy. Lastly, I would like to thank the meinbers and editors of the California Law Review for their labor and contributions to this Comment.

I. I Timothy 6:10 (The New Revised Standard Version, I989).

2. Marcel Krzystek, The Recent Congressional Reform of Federal Civil Forfeitures, 9 Kan. J.L. \& PuB. PoL'y 669 (2000). The types of connections that can trigger forfeiture include suspicion that the property was used to facilitate or was purchased with proceeds of criminal activity. See Eric Blumenson \& Eva Nilsen, Policing for Profit: The Drug War's Hidden Economic Agenda, 65 U. CHI. L. REv. 35, 44-46 (1998).

3. Blunenson \& Nilson, supra note 2 at $39-40$.

4. Id. at $48-49$. 
dealers because buyers carry seizable cash while dealers carry drugs that can only be destroyed. ${ }^{5}$ The result is that while a department may increase its forfeiture moneys, there is little reduction in the supply of drugs circulating within the community. ${ }^{6}$ Additionally, civil asset forfeiture averts the political accountability of law enforcement agencies by allowing them to finance themselves independently of funding from state or local legislatures. ${ }^{7}$ Lastly, law enforcement agencies' financial stake in civil asset forfeiture is problematic because it encourages overzealousness in the pursuit of forfeiture at the expense of the property owners. ${ }^{8}$

Law enforcement overzealousness is especially problematic given claimants' limited procedural rights in civil asset forfeiture proceedings. ${ }^{9}$ A civil asset forfeiture proceeding is characterized as a government action against the property rather than the property owner..$^{10}$ In fact, the government can seize property without prosecuting or even charging the property owner with a crime. ${ }^{11}$ Not officially a party in the action, the property owner does not, for example, have the right to an attorney or enjoy the presumption of innocence, but may bear the burden of proving that the seized property is not connected to criminal activities. ${ }^{12}$ High profile incidents, in which police had shot and killed individuals in their homes in the course of forfeiture activities, and later failed to connect the property to criminal activities, demonstrate civil forfeiture's susceptibility to abuse by moneyminded officials. ${ }^{13}$

Movements to reform civil asset forfeiture have focused on increasing the procedural burdens of law enforcement agencies by granting property owners rights and protections in forfeiture proceedings. Such protections include the right to a jury trial, a requirement that the property owner be convicted of a crime, the right to sue law enforcement agencies for damages and attorneys' fees for successful claimants, and protections for "innocent owners" who did not have knowledge that their property was used or involved in illegal activities. ${ }^{14}$ This Comment argues, however, that as long as the underlying financial reward exists for law enforcement

5. Id. at 56 .

6. Id.

7. Id. at 94 .

8. See Brant C. Hadaway, Comment, Executive Privateers: A Discussion on Why the Civil Asset Forfeiture Reform Act Will Not Significantly Reform the Practice of Forfeiture, 55 U. MIANI L. REv. 81, 81-83 (2000).

9. Id. at $99-100$.

10. Blumenson \& Nilsen, supra note 2 , at $46-47$.

11. Id. at $48-49$.

12. Id. at $47-48$.

13. See Hadaway, supra note 8, at 81-84.

14. See generally Paul S. Reed, States Reconsider Civil Forfeiture laws: Oregon, Washington and Utah Reconsider the Propriety of Temptation in Forfeiture (Feb. 9, 2001) (from About.com web site, on file with California Law Review) (discussing components of civil asset reform measures in Oregon, Utah, and Washington). 
agencies that participate in forfeiture, these agencies will not change their practices but instead will find ways to circumvent procedural safeguards.

California's experience with civil asset forfeiture reform, the focus of this Comment, suggests that procedural protections are not enough to change law enforcement agencies' behavior. Reform efforts in California have established siguificant procedural rights for property owners in civil asset forfeiture proceedings, but have not reduced law enforcement agencies' financial stake in forfeiture proceeds. ${ }^{15}$ As a result, the financial incentives for law enforcement agents to find and exploit loopholes in the forfeiture laws to avoid these procedural hurdles still remain.

This Comment reviews civil asset forfeiture generally and then focuses on California's civil asset forfeiture reform efforts and results. It argues that despite the need for procedural protections for property owners, only the elimination or drastic reduction of law enforceinent agencies' financial stake in forfeiture will successfully curb misuse of the forfeiture process by financially motivated law enforcement agencies. Part I describes the origin and evolution of civil asset forfeiture in the United States and discusses how civil asset forfeiture has survived several challenges in the Supreme Court. Part II details the financial incentives civil asset forfeiture creates for law enforcement agencies and the resulting abuses of the forfeiture process. Part III discusses the political context and process that led to the current California civil asset forfeiture laws and highlights lessons that instruct the reform proposal discussed in Part V. Part IV describes ways in which law enforcement agencies circumvent the procedural protections afforded by the California law, at times with the blessings of the state courts. ${ }^{16}$ Finally, Part V outlines several reform proposals, including the California legislature's recent efforts to close some of the loopholes described in Part IV. These proposals take aim at the underlying economic incentives that drive civil asset forfeiture. Part V also offers a proposal that targets these incentives and is tailored to the current political and economic climate in California.

15. See Cal. Health \& SafeTy CODE $\S 11488.4$ (i)(3) (West 2001) (requiring an underlying criminal conviction to support a judgment of forfeiture); $\$ 11488.4(\mathrm{i})(1)$ (entitling property claimants to a jury finding of forfeitability beyond a reasonable doubt); $\$ 11488.6(a)$ (preventing forfeiture of property of third-party owners who did not know that their property was used for an illegal purpose); $\$ 11489$ (reimbursing related costs and directing $65 \%$ of remaining forfeiture proceeds to participating law enforcement agencies).

16. See, e.g., Horton v. City of Oakland, 98 Cal. Rptr. 2d 371, 378 (Cal. Ct. App. 2000) (upholding local forfeiture ordinance that provides fewer procedural protections). 
The Development, Use, and Constitutionality of Civil Asset FORFEITURE

\section{A. The Development of Civil Asset Forfeiture in the United States}

Civil asset forfeiture has ancient roots; according to the Supreme Court, it can be traced to a biblical mandate to punish a guilty object for causing harm. ${ }^{17}$ Its common law origins can be traced to England. For example, English common law required animals or other objects that caused the death of a person to be forfeited to the Crown or to charity to atone for the death. ${ }^{18}$ In these cases, forfeiture actions proceeded against the animal or object as the wrongdoer, and the owners' lack of culpability would not prevent the forfeiture. ${ }^{19}$ English law also employed actions, known as in rem proceedings, against vessels to enforce admiralty laws when shipowners were overseas and beyond the jurisdiction of the English courts. ${ }^{20}$

America inherited this tradition. The earliest use of civil asset forfeiture in the United States was limited to forfeiture of maritime vessels engaged in piracy, smuggling, or the slave trade. ${ }^{21}$ During the Prohibition Era, the use of civil asset forfeiture expanded to allow the government to confiscate vehicles and equipment used to transport and manufacture alcohol. ${ }^{22}$ The government seized cars used to transport alcohol without the knowledge or consent of the owners, with the hope that the possibility of forfeiture would cause property owners to be more careful when allowing others to use their property. ${ }^{23}$

Civil asset forfeiture's role in American law enforcement continued to increase in the $1970 \mathrm{~s}$, when it became an integral part of the War on Drugs arsenal. The War on Drugs campaign consumes tens of billions of federal, state, and local dollars resulting in millions of arrests and record numbers of prosecutions and asset seizures. ${ }^{24}$ Congress considered drugs to be a significant source of crime, and believed that comprehensive and far-reaching

17. The Court traced forfeiture to biblical origins in the mandate that "[i]f an ox gore a man or a woman, and they die, he shall be stoned and his flesh shall not be eaten." Calero-Toledo v. Pearson Yacht Leasing Co., 416 U.S. 663, 681 n.17 (1974) (quoting Exodus 21:28). See also David Benjamin Ross, Comment, Civil Forfeiture: A Fiction That Offends Due Process, 13 Regent U. L. Rev. 259, 261 (2000-2001).

18. Marc. S. Roy, United States Federal Forfeiture Law: Current Status and Implications of Expansion, 69 Miss. L.J. 373, 374-75 (1999).

19. See id.

20. Ross, supra note 17.

21. Stefan D. Cassella, The Uniform Innocent Owner Defense to a Civil Asset Forfeiture: The Civil Asset Forfeiture Reform Act of 2000 Creates a Uniform Innocent Owner Defense to Most Civil Forfeiture Cases Filed by the Federal Government, 89 KY. L.J. 653, 656 (2000-2001).

22. Id. at 656-57.

23. Id.

24. Blumenson \& Nilsen, supra note 2, at 36-37. 
efforts were necessary to combat drug use. ${ }^{25}$ In 1970, Congress passed the Comprehensive Drug Abuse Prevention and Control Act, ${ }^{26}$ which authorized drug-related civil asset forfeiture. The purpose of the forfeiture provision was to strike at the economic roots of the drug trade by divesting drug lords of the capital used to fund and operate the drug trade, rather than by going after individual sellers who easily could be replaced. ${ }^{27}$

The popularity of civil asset forfeiture as a tool in the War on Drugs operations increased as the range of forfeitable property expanded over the years. ${ }^{28}$ The 1970 Act allowed for the seizure of drugs and manufacturing, storage, and transportation equipment used in drug activities. ${ }^{29}$ Today, property subject to forfeiture includes real property and any other property "traceable" to drug transactions, including cash, securities, or records. ${ }^{30}$ Also, in the Anti-Drug Abuse Act of $1986,{ }^{31}$ Congress authorized seizure of property equal in value to forfeitable property that is no longer available or accessible.

In 1984, Congress further expanded the scope of the civil asset forfeiture authority and its use by federal and state law enforcement agencies. It amended the forfeiture law to allow federal law enforcement agencies to keep forfeiture proceeds rather than deposit them in the Treasury's General Fund and to share these proceeds with state and local law enforcement. ${ }^{32}$ Thus, in addition to federal funding of state law enforcement activities in the war on drugs, ${ }^{33}$ civil asset forfeiture proceeds have grown in importance as an additional mechanism by which law enforcement agencies finance their War on Drugs operations. ${ }^{34}$

\section{B. The Modern Civil Asset Forfeiture Process}

The government's expansive authority under civil asset forfeiture laws is supplemented by other practical benefits. Modern civil forfeiture proceedings are instituted against the property as an in rem action, based on the notion that the property, not the owner, is the guilty party. ${ }^{35}$ This

25. Douglas Kim, Comment, Asset Forfeiture: Giving Up Your Constitutional Rights, 19 CAMPBell L. REV. 527, 561-62 (1997).

26. Pub. L. No. 91-513, 84 Stat. 1242 (1970) (the relevant portion affecting civil forfeiture is codified as 21 U.S.C. $\$ 881$ ).

27. See Blumenson \& Nilsen, supra note 2, at 44.

28. Hadaway, supra note 8 , at $92-93$.

29. 21 U.S.C. $\$ 881(\mathrm{a})(2001)$.

30. Id.

31. 21 U.S.C. $\S 853(\mathrm{p})(2001)$.

32. 28 U.S.C. $\$ 524(2001)$.

33. See Blumenson \& Nilsen, supra note 2, at $42-44$.

34. See id. at $40-41$.

35. Id. at $47 \mathrm{n} .48$. Civil forfeiture should be distinguished from criminal forfeiture, in which the property owner's criminal conviction results in the forfeiture of property as part of the penalty for the unlawful act. See Robert Michael Dykes, Comment, Cache and Prizes: Drug Asset Forfeiture in California, 20 W. ST. U. L. REv. 633 (1993). 
makes civil asset forfeiture particularly useful when the government cannot locate, assert jurisdiction over, or for other reasons build a case against the property owners, because it allows the government to proceed against the property itself in the owner's absence. ${ }^{36}$

Typically, government officials can seize property without notice or hearing, based on an ex parte showing of probable cause to believe that the property is connected to a crime. ${ }^{37}$ The connection can range from a suspicion that the property is contraband or the instrumentality of a crime, to a belief that the property facilitated a crime or is representative of proceeds of criminal activity. ${ }^{38}$ Because the focus is on the property and its suspected criminal ties, the government need not bring charges against the owner or anyone else. ${ }^{39}$

After the government seizes the property, it is up to the owner to decide whether to contest the forfeiture at a hearing at which many constitutional rights available to criminal defendants do not apply, or to count the property as lost. ${ }^{40}$ An owner who decides to contest the forfeiture has the burden of showing that, contrary to the government's suspicions, the property is not actually connected to criminal activities. ${ }^{41}$ In other words, once the government seizes an asset the asset cannot be recovered unless the owner, through the use of her limited procedural rights, successfully proves a negative and demonstrates the innocence of her property.

Civil asset forfeiture offers prosecutors and police broad authority and financial reward with minimal procedural burdens. Civil asset forfeiture's popularity with law enforcement agencies has not, however, quelled its opponents, including both civil libertarians and property owners. Objections to the procedural and constitutional inadequacies of civil forfeiture proceedings are discussed in the next section. As important as it may be to remedy these inadequacies, however, this Comment argues that the distortion of law enforcement objectives and abuse by law enforcement agencies will diminish only with a significant reduction of law enforcement agencies' financial stake in civil asset forfeiture.

36. Ross, supra note 20 , at 261.

37. CATO Congressional Testimony: The Civil Forfeiture Reform Act 1997, Statement Before the House Comm. on the Judiciary (June 11, 1997, Statement of Roger Pilon), at http://www.cato.org/testimony/ct-rp061197.html.

38. Id.

39. Id.

40. Id. See, e.g., Murray v. Carrier, 477 U.S. 478 (1986) (holding that property owners are not entitled to free counsel); United States v. U.S. Coin \& Currency, 401 U.S. 715 (1971) (holding that the right against self-incrimination has limited application in forfeiture cases); United States v. Zucker, 161 U.S. 475 (1896) (holding that the right to confront adverse witnesses does not apply in forfeiture proceedings).

41. Id. See also Krzystek, supra note 2, at 674-76 (discussing the standard of proof and the shifting burden in civil asset forfeitures). 


\section{Procedural and Constitutional Challenges to Civil Asset Forfeiture}

Civil asset forfeiture implicates a variety of constitutional rights. The Supreme Court, however, has rebuffed most constitutional challenges by finding that the particular constitutional right either does not apply in a civil proceeding, or that it cannot be asserted by the property owner, who is not officially a party to the proceeding.

One objection to civil asset forfeiture is that it arguably violates the Double Jeopardy Clause of the Fifth Amendment when employed in conjunction with a criminal trial. ${ }^{42}$ If a defendant is convicted and sentenced at the conclusion of a criminal proceeding, a procedure resulting in seizure of his property based on the same underlying crime seems to subject him to a second penalty for the same act. ${ }^{43}$ However, in United States v. Ursery, the Supreme Court rejected this argument on two grounds. ${ }^{44}$ First, the Court held that forfeiture proceedings are civil in nature and are not meant to be a punishment for a criminal offense. ${ }^{45}$ Thus, "forfeiture is not barred by the Double Jeopardy Clause of the Fifth Amendment because it involves neither two criminal trials nor two criminal punishments." ${ }^{46}$ Second, the Court relied on the legal fiction that in rem forfeiture is a remedial action against the property, rather than a punitive sanction against the property owner." The Court held fast to its "traditional understanding that civil forfeiture does not constitute punishment for the purpose of the Double Jeopardy Clause. $\$ 48$

Another constitutional challenge brought against civil asset forfeiture is that it fails to provide legal representation for defendants, as guaranteed by the Sixth Amendment. The Sixth Amendment provides in part, "[I]n all criminal prosecutions, the accused shall enjoy the right . . to have the Assistance of Counsel for his defence." 49 Courts have uniformly relied on civil asset forfeiture's technical status as a civil proceeding to reject Sixth Amendment challenges, despite the involvement of law enforcement agencies and other similarities to criminal proceedings. ${ }^{50}$ Claimants whose assets have been seized have a right to rebut the presumption of forfeitability at a hearing, but are generally not permitted to use those assets to retain a

42. The Double Jeopardy Clause provides, "[N] or shall any person be subject for the same offence to be twice put in jeopardy of life or limb." U.S. ConsT. amend. V.

43. See United States v. Ursery, 518 U.S. 267, 270-72 (1996) (describing the Sixth and Ninth Circuits' holdings that the Double Jeopardy Clause "prohibits the Government from both punishing a defendant for a criminal offense and forfeiting his property for that same offense in a separate civil proceeding," and the facts of the cases that led to those holdings).

44. Id. at $274,280$.

45. Id. at 275.

46. Id. at 276 (quoting One Lot Emerald Cut Stones v. United States, 409 U.S. 232 (1972)).

47. Id. at 278-79.

48. Id. at 287 .

49. U.S. CoNsT. amend. VI.

50. Kim, supra note 25 , at 573. 
lawyer. ${ }^{51}$ Even when they cannot afford representation, they are not guaranteed a court-appointed attorney. ${ }^{52}$ This is a significant setback for property owners, because the value of seized assets can be significantly lower than the cost of contesting the forfeiture at a hearing. ${ }^{53}$ Some defense attorneys estimate that such a contest would cost at least $\$ 10,000$ and will not accept a case unless the forfeiture value is large. ${ }^{54}$ The expense may discourage contests. For example, it would not be economical to spend $\$ 10,000$ in attorney's fees to contest the forfeiture of a $\$ 5,000$ car. Yet again, the "civil" nature of forfeiture proceedings renders a constitutional protection ineffectual. ${ }^{55}$

The Due Process Clauses of the Fifth and Fourteenth Amendments ${ }^{56}$ provide another basis for challenging forfeiture laws. Due process requires the opportunity for a timely and meaningful hearing before the deprivation of property. ${ }^{57}$ Civil asset forfeiture falls short of this requirement when the seizure of property precedes a contest hearing. ${ }^{58}$ However, in Bennis $v$. Michigan the Court rejected due process challenges to civil asset forfeiture..$^{59}$ Tina Bennis jointly owned a car with her husband, who was caught having sex with a prostitute in the car. ${ }^{60}$ Pursuant to state law, the State of Michigan sued to have the car declared a public nuisance and forfeited. ${ }^{61}$ Mrs. Bennis claimed that the seizure denied her due process rights because she was not permitted to defend against the seizure by showing that she was not aware of and did not consent to her husband's use of the car. ${ }^{62}$ The Court upheld the forfeiture because the case turned on the car's connection to a criminal act; according to the Court, Mrs. Bennis's innocence was entirely irrelevant to the constitutionality of the forfeiture. ${ }^{63}$ As in Ursery, the

51. Id. at 572 .

52. See, e.g., Murray v. Carrier, 477 U.S. 478 (1986) (holding that property owners are not entitled to free counsel simply because the government lays claim to their property); United States v. Doe, 743 F.2d 1033, 1038 (4th Cir. 1984) (holding that a defendant's right to appointed counsel is triggered by "only offenses where a sentence of imprisonment is imposed").

53. Krzystek, supra note 2, at 672.

54. Karen Dillon, Across U.S., Police Dodge State Seizure Laws, KanSas City Star, May 19, 2000 , at 1 .

55. See, e.g., United States v. One 1982 Chevrolet Crew-Cab Truck, 810 F.2d 178, 183 (8th Cir. 1987) (holding that the "full panoply of constitutional protections afforded criminal defendants is not available in the context of such forfeiture proceedings").

56. The Fifth Amendment provides in part, "[N]or shall any person ... be deprived of life, liberty, or property, without due process of law." U.S. CoNST. amend. V. The Fourteenth Amendment Due Process Clause provides, "[N]or shall any state deprive any person of life, liberty, or property, without due process of law." U.S. CONST. amend. XIV.

57. See Matthews v. Eldridge, 424 U.S. 319, 333 (1976).

58. See Pilon, supra note 37.

59. 516 U.S. 442 (1996).

60. Id. at 443 .

61. Id.

62. Id. at 446 .

63. Id. at 447 . 
legal fiction that civil asset forfeiture is an action against property obscured the practical effect and severe penalty imposed on the property owner.

Bennis also addressed another constitutional objection to civil asset forfeiture. Bennis argued that because the police took permanent possession of her vehicle, the forfeiture constituted a taking of her private property for public use without just compensation in violation of the Fifth Amendment's Takings Clause. ${ }^{64}$ The Court dismissed Bennis's Takmgs claim, stating:

[I]f the forfeiture proceeding here in question did not violate the Fourteenth Amendment, the property in the automobile was transferred by virtue of that proceeding from petitioner to the State. The government may not be required to coinpensate an owner for property which it has already acquired under the exercise of governmental authority other than the power of eminent domain. ${ }^{65}$

In other words, since the forfeiture, which did not violate Mrs. Bennis's Fourteenth Amendment rights, served as a legitimate basis for Michigan to take possession of Mrs. Bennis's car, Michigan could do so without invoking its eminent domain authority and was not required to compensate her.

Claims of Eighth Amendment ${ }^{66}$ violation have also been raised against civil asset forfeiture, especially when seizure is triggered by a minor drug infraction such as possession. ${ }^{67}$ The Court has held that civil asset forfeiture proceedings are subject to the Eighth Amendment's prohibition against excessive fines. ${ }^{68}$ However, the Court rejected a specific requirement of proportionality between the value of the asset to be forfeited and the gravity of the defendant's offense, and left it for the lower courts to decide whether specific forfeiture actions were excessive on a case-bycase basis. ${ }^{69}$ In 1998, citing the need for courts to defer to legislative penal decisions, the Court established a test that requires "gross

64. Id. at 452. The Fith Amendment provides in part, "[N]or shall private property be taken for public use, without just compensation." U.S. CoNST. amend. V.

65. Bennis, 516 U.S. at 452-53.

66. The Eighth Amendment provides, "Excessive bail shall not be required, nor excessive fines imposed, nor cruel and unusual punishments inflicted." U.S. CoNST. amend. VIIl.

67. See, e.g., Austin v. United States, 509 U.S. 602 (I993). In Austin, the United States initiated forfeiture proceedings against the defendant's mobile home and body shop after the defendant pleaded guilty to selling two grams of cocaine to an undercover police officer and was sentenced to seven years in prison. Id. at 604-05. See also United States v. One 1986 Mercedes Benz, 846 F.2d. 2, 4-5 (2d Cir. I988) (holding that less than one ounce of marijuana is sufficient for the forfeiture of a car); Rebecca A. Brommel, Note, A Constitutional and Statutory Assessment of Civil Forfeiture of an Intoxicated Driver's Vehicle: Should Iowa Follow the "Get-Tough" Approach?, 49 DRAKE L. REv. 64I, 663 (2001) (describing New York City policy of seizing vehicles after the registered owner has been arrested for drunk driving, even in cases of a flrst offense).

68. See Austin, 509 U.S. at 610 .

69. Id. at 622-23. 
disproportionality" for a finding that a forfeiture is unconstitutionally excessive. ${ }^{70}$

Even in the few cases where the Supreme Court has found that a constitutional protection should apply in civil asset forfeiture proceedings, ${ }^{71}$ the protection often proves illusory in subsequent lower court decisions. For example, the Court has recognized that a claimant's due process rights include the right to notice of a seizure and an opportunity for a hearing unless "extraordinary situations" justify postponement of notice. ${ }^{72}$ Mathews v. Eldridge sets out three factors to determine whether circumstances are extraordinary: (1) the nature of the private interest at stake, (2) the risk of error associated with the procedure used, and (3) the government's interest, including the administrative burden of a more elaborate procedure. ${ }^{73}$ Application of these factors has resulted in exceptions in almost all cases involving personal property. ${ }^{74}$ Presumably, the reasoning is that a mobile object can easily move out of the court's jurisdiction and would do so unless seized immediately, without delays that may result from notice and hearing. ${ }^{75}$

Similarly, the Court has held that in a civil forfeiture proceeding based on the owner's criminal offense, the owner-defendant can exercise her Fifth Amendment right against self-incrimination. ${ }^{76}$ In practice, however, the defendant may have to choose between exercising her right to remain silent and vigorously contesting forfeiture of her property, because the government can use her statements at a forfeiture hearing for purposes of criminal prosecution. ${ }^{77}$ In United States v. Certain Real Property 566 Hendrickson Boulevard, the defendant claimed that any attempt to challenge a civil forfeiture may potentially expose him to self-incriminating statements and would effectively waive his right. ${ }^{78}$ The Sixth Circuit held that the forfeiture action could proceed and was not barred just because the defendant may possibly be "disadvantaged" by remaining silent during the proceeding. ${ }^{79}$

70. United States v. Bajakajian, 524 U.S. 321,324 (1998).

71. See e.g., Fuentes v. Shevin, 407 U.S. 67 (1972) (recognizing forfeiture claimants' due process right to notice of seizure and opportunity for a hearing).

72. Id. at 80 .

73. 424 U.S. 319,335 (1976).

74. See United States v. Von Neumann, 474 U.S. 242, 251 (1986) (waiving the hearing requirement for custom agents who seized a car at the border); Calero-Toledo v. Pearson Yacht Leasing Co., 416 U.S. 663 (1974) (allowing the seizure of a yacht without prior notice and hearing because the yacht might have left the jurisdiction if the government had given advance notice).

75. See Kim, supra note 50, at 563 .

76. The Fifth Amendment provides in part, "[N]or shall be compelled in any criminal case to be a witness against himself." U.S. CoNST. amend. V.

77. See, e.g., United States v. Certain Real Property 566 Hendrickson Boulevard, 986 F.2d 990 (6th Cir. 1993).

78. Id. at 996 .

79. Id. 
In sum, although civil asset forfeiture seems potentially violative of the Fifth, Sixth, Eighth, and Fourteenth Amendments, the Court tends to either disagree or offer protections that can be easily circumvented. As will be seen in Part III, some states, including California, have tried to provide more protection than is required by the Supreme Court. ${ }^{80}$ However, even California has failed to address one of the most pressing practical difficulties: the financial incentives for law enforcement agencies to abuse civil asset forfeiture. Until these incentives are directly addressed, civil asset forfeiture will continue to be problematic. These incentives are the subject of the next Part.

II

\section{The Fundamental Defect of Civil Asset Forfeiture: The FINANCIAL INCENTIVES}

While constitutional objections and efforts to reform civil asset forfeiture have generally emphasized procedural inadequacies, a more fundamental defect is often overlooked: law enforcement agencies' direct financial stake in the proceeds of forfeited property. Law enforcement agencies, including police departments that participate in raids and seizures and district attorneys' offices that prosecute the forfeiture actions, keep the bulk of the proceeds from successful forfeitures; thus, these agencies have an incentive to tailor their activities to maximize forfeitures. ${ }^{81}$ The incentive to maximize forfeiture funds sometimes results in the displacement of legitimate law enforcement objectives in pursuit of financially rewarding forfeitures ${ }^{82}$ The result is a distortion of law enforcement policies: assets and their seizure, rather than crime, are targeted.

This distortion can be seen in various types of police behavior. For example, some police departments prefer to arrest drug buyers rather than dealers because buyers have cash with them. ${ }^{83}$ The New York City Police Department imposes roadblocks on the southbound lanes of I-95 toward New York City, which carry drug buyers and their cash, rather than the northbound lanes, which carry drivers who have already purchased drugs. ${ }^{84}$ The result is that the cash is seized by and forfeited to the police, while the drugs, which the police could only destroy, are left in circulation. ${ }^{85} \mathrm{~A}$

80. In New Mexico, for example, civil asset forfeiture proceedings are prohibited as violation of double jeopardy after the criminal conviction and sentencing of the owner. See State v. Nunez, 2 P.3d 264, 293 (N.M. 1999) ("The New Mexico Double Jeopardy Clause forbids bringing criminal charges and civil forfeiture petitions for the same crime in separate proceedings. Our holding is unaffected by whether jeopardy attached first in the criminal proceeding or in the civil forfeiture action.").

81. Blumenson \& Nilsen, supra note 2, at 56.

82. Id.

83. Id.

84. Id. at 68 .

85. Id. at $56-84$. 
similar practice is the "reverse sting," in which police officers pose as dealers rather than buyers. ${ }^{86}$ This tactic allows police departments to seize buyers' cash rather than sellers' drugs. ${ }^{87} \mathrm{~A}$ final example of the distortive effects of the financial incentives of asset forfeiture is its effect on the plea bargain process: dealers who are higher on the drug trade hierarchy and whose imprisonment is presumably more important for drug enforcement objectives receive lesser penalties because they are able to disclose to police their forfeitable assets. ${ }^{88}$ In short, because of the financial incentives involved, forfeiture has become a means for financial gain rather than just an effective method of fighting the war on drugs.

Giving law enforcement agencies a portion of the assets that they seize also leads to questionable practices and overzealous pursuit of forfeitures, to the detriment of the public. The influence of civil asset forfeiture's financial incentives can be seen in some police departments" "structured arrests" policies, in which undercover agents attempt to locate transactions on valuable land so that the property can be forfeited to the department. ${ }^{89} \mathrm{~A}$ similar forfeiture-driven policy was that of the officers from the Volusia County Sheriff's Office in Florida who stopped vehicles on southbound I95 and routinely confiscated any money over one-hundred dollars under the assumption that money in such quantity must be drug money. ${ }^{90}$ The same officers often haggled with the motorists during these stops, allowing the motorists to retain a portion of the money in exchange for an agreement not to contest the seizure. ${ }^{91}$ This policy also took advantage of the fact that contesting the seizure of a few hundred dollars is uneconomical given the high legal fees involved and the inconvenience to out-of-state tourists. ${ }^{92}$

The financial incentives also produce an overzealousness in pursuing forfeiture leads that in at least one case has produced tragic results. In 1992, sixty-one-year-old Donald Scott, a reclusive millionaire, was shot and killed by a twenty-seven-person police task force executing a search warrant for marijuana plants. ${ }^{93}$ A subsequent investigation into Scott's death by the Ventura County District Attorney concluded that the possibility of acquiring his two-hundred-acre Malibu ranch and other assets supplied the primary motivation for the raid, which failed to produce any evidence of criminal activity. ${ }^{94}$ The police found neither marijuana nor any

86. Id. at 67.

87. Id.

88. Id. at 72 (citing examples, including that of a New Jersey "drug kingpin" whose twenty-fiveyears-to-life indictment was dropped in exchange for parole eligibility in five years and an agreement to forfeit $\$ 1$ million in assets).

89. Ross, supra note 20, at 272-73.

90. Id. at 273 .

91. Id.

92. Krzystek, supra note 2, at 673.

93. Hadaway, supra note 8 , at $82-83$.

94. Id. at 83. 
drug paraphernalia on Scott's property.$^{95}$ The investigation revealed that the search warrant was based on false evidence used to establish probable cause, ${ }^{96}$ and that the police had intended to seize the ranch and to sell it to the National Park Service, which had previously made several attempts to purchase the land. ${ }^{97}$ The twenty-seven-member team that executed the search warrant and killed Scott included inembers of several law enforcement agencies. However, it did not include the county sheriff in whose jurisdiction Scott's ranch was located because the organizers of the raid did not want to split the expected forfeiture proceeds with the county police. ${ }^{98}$

While they are not the only cases in which the prospect of a lucrative forfeiture has led to overzealous law enforcement actions based on weak or no criminal connections, ${ }^{99}$ Scott's case and "structured arrest" policies illustrate the specific and prominent role that potential monetary gains from forfeiture can play in shaping or dictating law enforcement actions. These cases highlight the tangible dangers of giving law enforcement agencies the tools to self-finance; financial rewards encourage law enforcement to seize first and ask questions later.

Finally, the ability of law enforcement agencies to self-finance through civil asset forfeiture enables thein to escape political accountability. ${ }^{100}$ Self-financing through civil asset forfeiture evades accountability in several ways. Unlike most other governmental units, which exclusively depend on the legislative budget process for funding, law enforceinent agencies can generate a substantial portion of their own budgets through forfeiture proceeds. In fact, some agencies depend heavily or entirely on forfeiture proceeds for their operating budgets. ${ }^{101}$ This circumvents both political oversight and fiscal restraints that typically hold agencies accountable to their political constituencies. ${ }^{102}$ Law enforcement agencies' independence from the legislature comes with a corresponding dependence on civil asset forfeiture proceeds to sustain their programs and budgets and perhaps an even stronger incentive to zealously pursue forfeiture actions,

95. Blumenson \& Nilsen, supra note 2, at 74.

96. Roy, supra note 18 , at 416.

97. Susan Meeker-Lowry, Asset Forfeiture, Z-MAGAZINE (Jan. 1996), at http://www.zmag.org/ zmag/articles/jan96meeker.htm.

98. Roy, supra note 18 , at 416 .

99. See Hadaway, supra note 8, at 81-84. See also Blumenson \& Nilsen, supra note 2, at 81-83 (describing specific examples of police department policies and practices, some illegal, based on maximizing forfeiture intake); Barbara Metzler, State Asset Forfeiture Law Faces Change; Drug Convictions Will Be Needed, Press ENTERPRISE, Nov. 15, 1993, at B3 (citing a 1991 investigation that found " 80 percent of those who forfeit property to the government are never charged with a crime").

100. Blumenson \& Nilsen, supra note 2, at 84.

101. Hadaway, supra note 8, at 94-95.

102. Id. at 84-95. 
leading to the kind of problematic policies and practices discussed above. ${ }^{103}$

Self-financing through forfeiture proceeds deprives legislators, for whom direct challenges to law enforcement's War on Drugs authority can be political suicide, of the use of appropriations as a means to indirectly influence law enforcement policies. ${ }^{104}$ Self-financing also short-circuits legislative determination of how much is an appropriate level of spending for particular law enforcement activities or resources. ${ }^{105}$ Lastly, there is limited accountability in how law enforcement agencies spend the money they receive from forfeitures. ${ }^{106}$ There are various accounts of questionable uses of forfeiture proceeds or assets, including personal uses by law enforcement agents that suggest that the forfeiture was motivated by the ultimate use of the property. ${ }^{107}$

Also, due to the overlapping federal and state jurisdiction in drugrelated crimes, law enforcement agencies can circumvent regulation by attributing forfeiture activities to an agency in the other jurisdiction. ${ }^{108}$ As will be discussed in greater detail in Part IV, attribution of forfeiture actions to the federal government is a common means by which state law enforcement agencies bypass the procedural hurdles or distribution schemes under state law. ${ }^{109}$

In sum, although the procedural objections to civil asset forfeiture are more conspicuous and more often raised, the tendency toward abuse of forfeiture proceedings cannot be stopped without addressing the very practical impact of financial incentives. This problem becomes clear upon a close look at California's attempts at civil asset forfeiture reform. Despite the state's commendable procedural reforms, law enforcement abuses of forfeiture proceedings have continued because the reform effort failed to substantially alter the financial incentives created by civil asset forfeiture.

\section{III}

California's EFForts to Reform Its Drug Forfeiture LaWs

California was the first state to attempt a large-scale reform of its civil asset forfeiture laws, resulting in the enactment of its current civil asset

103. John Dillin, Government's Big Grab: Civil Forfeiture, Christian ScIEnce Monitor, Oct. 5,1993 , at 6 .

104. Blumenson \& Nilsen, supra note 2, at 78, 99.

105. Id. at 89 .

106. Krzystek, supra note 2, at 675.

107. Id. at 673-74. For example, these uses include keeping forfeited vehicles for personal uses, reselling forfeited real property at a fraction of its value to friends and family of the forfeiting law enforcement agencies, and using forfeiture funds to purchase personal property such as furniture. Id.

108. Blumenson \& Nilsen, supra note 2, at 94.

109. Id. 
forfeiture law on August 19, 1994. ${ }^{110}$ This reform effort took place in a unique context during the 1993 legislative session: California's thenexisting civil asset forfeiture law was scheduled to expire (or sunset) on December 31, 1993, and no one was sure of the effect of that sunset date if a new law was not enacted in its place. ${ }^{111}$ As will be discussed in this Part, this uncertainty induced interested parties to comproinise. The reform effort also built an atypical coalition that served as a formidable political opponent for the law enforcement lobby. ${ }^{112}$ A sensitivity to both the context and effective coalition-making informs the reform proposal offered in Part IV.

The bill that became California's drug-related civil asset forfeiture law ("drug forfeiture law") added significant procedural safeguards to the forfeiture process but did not alter the distribution of, or law enforcennent's direct financial stake in, forfeiture proceeds. ${ }^{113}$ Procedural protections, however, have proven to be inadequate in compelling changes in law enforcement conduct in forfeiture actions. Instead, the financial rewards of civil asset forfeiture drive law enforceinent agencies to circumvent procedural safeguards by finding and exploiting loopholes, soine of which were left in place because of political compromises.

\section{A. The Context of the Reform Effort}

California's drug-related civil asset forfeiture statute first came into existence in $1989 .{ }^{114}$ Before that, drug-related forfeiture existed only under the state's criminal forfeiture scheme, and required criminal conviction of the person connected to the property; civil asset forfeiture in California was largely the domain of federal agencies. ${ }^{115}$ Effective January 1, 1989, California amended its forfeiture statutes and enacted the Comprehensive Forfeiture Act ("CFA"), which tracked federal statutes to authorize civil forfeitures with substantially more relaxed procedural requirements. ${ }^{116}$ For example, CFA did not require a criminal conviction to support forfeiture; rather, the state was only required to demonstrate that property was subject to forfeiture by a preponderance of the evidence. ${ }^{117}$

110. Complete Bill History, A.B. 114, 1993-1994 Reg. Sess. (Cal. 1994), available at www.leginfo.ca.gov/pub/93-94/bill/asm/ab_0101-0150/ab_114_bill_history (last visited May 1, 2002).

111. See Bill Ainsworth, Compromise Reached on Asset Forfeiture Bill, THE RECORDER, Aug. 16, 1994, at 3. [hereinafter Ainsworth, Compromise Reached].

112. Greg Lucas, Unusual Alliance in Battle Over Asset Forfeiture Laws, S.F. Chron., Apr. 20, 1993, at Al5.

113. See supra note 15.

114. Robert Michael Dykes, Cache and Prizes: Drug Asset Forfeiture in California, 20 W. ST. U. L. REV. 633, 635 (1993).

115. See id at 634-36 (discussing Califomia's drug-related asset-forfeiture laws prior to the 1994 amendments).

116. Id.

117. Cal. Health \& SafeTy Code $\$ 11488.4$ (i) (West 2001). 
CFA was scheduled to expire on January 1, 1994. ${ }^{118}$ However, the precise result of the sunset provision was unclear. If CFA expired, the law governing asset forfeiture might either revert back to its pre-CFA form or drop off the books entirely, effectively ending civil asset forfeiture in California. ${ }^{119}$ This uncertainty set the stage for competing visions of how civil asset forfeiture laws should be instituted. On one side stood law enforcement groups, who insisted that asset forfeiture continue. They insisted that, at the very least, pre-CFA laws allowing criminal forfeiture be allowed to continue, but this was not their ideal choice because the pre-CFA laws required a criminal conviction before assets could be seized; they argued in favor of reenacting CFA or at least putting new laws on the books that would not be as limiting as the pre-CFA laws. ${ }^{120}$

Groups interested in reforming civil asset forfeiture practices, including both civil libertarians and property owners, constituted the other side. These groups also wanted to seize this opportunity to restructure civil asset forfeiture in California, especially in the aftermath of the 1992 shooting of Donald Scott at the hands of law enforcement agents interested in seizing his property. ${ }^{121}$ The upcoming sunset date gave reformers a rare upper hand in negotiating with law enforcement groups. From the point of view of law enforcement, the best-case scenario in the absence of negotiation if CFA were to expire, was a reversion back to the pre-CFA laws that siguificantly limited their discretion in forfeiture actions. ${ }^{122}$ The scenario that law enforcement groups most feared was that CFA would expire and all asset forfeiture in California would end. Faced with this possibility, law enforcement groups were eager to negotiate. Both sides therefore had incentives to come to the negotiation table. ${ }^{123}$

In this atmosphere, two competing bills were introduced. Assembly Bill ("AB") 114, introduced by then-Assemblymember (now State Senator) John Burton, ${ }^{124}$ was backed by an unusual conglomerate of banking and real estate interests, restaurant owners, and criminal defense lawyers. ${ }^{125} \mathrm{AB} 114$ would have added significant procedural safeguards to protect property owners. First, it would have extended the notification

118. Id.

119. See Bill Ainsworth, Asset Forfeiture Appears on lts Way Out in S.F., THE ReCORDER, Mar. 11, 1994, at 3 [hereinafter Ainsworth, Way Out].

120. Bill Ainsworth, Forfeiting Asset Forfeiture: By Playing Rough in Capitol Negotiations, Lungren and DAs End Up with a Seizure Law Civil Libertarians Prefer, The ReCorder, Sept. 14, 1993, at 1 [hereinafter Ainsworth, Forfeiting Asset Forfeiture].

121. See Metzler, supra note 99 at B3.

122. Bill Ainsworth, Seizing the Day: Concerned About Wanton Property Seizures in Drug Cases, Traditionally Conservative Groups Are Supporting a Liberal's Attempt to Scale Back the State Asset-Forfeiture Law, THE ReCorder, Aug. 17, 1993, at 1 [hereinafter Ainsworth, Seizing the Day].

123. Id.

124. Complete Bill History, A.B. 114, supra note 110.

125. Ainsworth, Seizing the Day, supra note 122. 
requirement to community-property owners in addition to the legal owner, and extended service of process to all reasonably discoverable owners of the property rather than just people specifically designated in a receipt issued for the seized property, as under CFA. ${ }^{126}$ Second, AB 114 would have prohibited forfeiture of property unless its owner had been convicted of a drug offense that would subject the property to forfeiture. ${ }^{127}$ It also would have required the government to prove that the property was subject to forfeiture (1) to a jury, rather than a judge, and (2) by the highest standard: "beyond a reasonable doubt."128 Additionally, AB 114 would have prohibited the seizure of property during the pendency of forfeiture proceedings if the seizure would place an undue burden on any owner, and it further placed a burden on the court to show that alternative orders to protect the potential interest of the parties, ones that do not require seizure of the property, would not be available. ${ }^{129}$ Finally, AB 114 would have required courts to evaluate whether the value of the seized property was proportional to the gravity of the underlymg conviction. ${ }^{130}$ In sum, $A B 114$ addressed many of the procedural objections that could have been raised against its predecessor, CFA.

More significantly, AB 114 also addressed the underlying economic incentives of the forfeiture system. First, it would have directed the bulk of forfeiture proceeds to the General Fund. ${ }^{131}$ Additionally, AB 114 would have permitted successful claimants to recover attorney's fees from the state; this would have reduced law enforcement agencies' mcentives to pursue meritless forfeiture actions in the hope that the forfeitures would be too uneconomical to contest. ${ }^{132}$ In these ways, AB 114 sought to sever the connection between the proceeds of forfeiture and the agencies that controlled the process, and to create sanctions for improper actions.

In stark contrast to AB 114, Senate Bill ("SB") 1158 aimed to expand the forfeiture authority of law enforcement agencies. ${ }^{133}$ It was introduced in the Senate by Republican State Senator Ken Maddy and backed by thenAttorney General Dan Lungren and law enforcement groups. SB 1158 would have extended the number and types of crimes that would trigger forfeiture; for example, growing marijuana would have been included. ${ }^{134}$ It also would have increased the statute of limitations, the time allowed between the commission of the underlymg crime and the seizures, from

126. A.B. 114, 1993-1994 Reg. Sess. (Cal. 1993) (as amended Apr. 1, 1993).

127. Id. $\$ 2$ (authorizing forfeiture of items used to commit drug offenses involving "manufacture, sale, possession for sale, offer for sale, or offer to manufacture").

128. Id. $\$ 12$.

129. Id.

130. Id. $\$ 19$

131. Id. $\$ 17$.

132. Id. $\$ 13$.

133. See Ainsworth, Seizing the Day, supra note 122.

134. S.B. 1158, 1993-1994 Reg. Sess. (Cal 1993) (as introduced Mar. 5, 1993). 
five to ten years ${ }^{135}$ and would have permitted seizure of property without notice by any peace officer who has "probable cause" to believe that the property is subject to forfeiture. ${ }^{136}$ SB 1158 also would have removed several then-existing procedural protections, such as the requirement that the government prove forfeitability by a preponderance of the evidence and the provision permitting an innocent spouse to keep $\$ 100,000$ from the sale of a seized home. ${ }^{137}$

More importantly, SB 1158 would not have altered CFA's allocation of forfeiture proceeds. ${ }^{138}$ Given the strong backing of this bill by law enforcement groups, this omission suggests that law enforcement groups were satisfied with CFA's allocation formula, which remitted the bulk of forfeiture proceeds to the prosecutorial and police agencies responsible for the acquisition. ${ }^{139}$

$\mathrm{AB} 114$ and SB 1158 were diametrically opposed in virtually every respect. $A B 114$ was authored by an Assembly Democrat known for his civil libertarian beliefs and sponsored by groups that bear the brunt of the forfeiture laws, including criminal defense attorneys and property owners. ${ }^{140}$ It offered to significantly expand the procedural due process rights available to forfeiture claimants and to undermine the financial profitability of forfeiture for law enforcement agencies. ${ }^{141}$ SB 1158, on the other hand, was authored by a Senate Republican leader and backed by an Attorney General known for his close ties to the law enforcement community, and proposed not only to enhance forfeiture authority, but also to curtail procedural safeguards. ${ }^{142}$

\section{B. The Legislative Process and Outcome}

Not surprisingly, AB 114 and SB 1158 were hotly contested throughout the legislative process as law enforcement groups squared off with property and civil libertarian groups. ${ }^{143}$ The sunset date that catalyzed both proposals, as well as the uncertainty of its effect both before and after the date arrived, induced each side to negotiate and to finally reach a compromise solution.

135. Id. $\S 1$.

136. Id. $\$ 3$.

137. Id. $\$ \S 13,18$.

138. Id. $\$ 19$.

139. Cal. Health \& SAFETy Code $\S 11489(2)$ (West 1993) (directing $65 \%$ of forfeiture proceeds to law enforcement agencies that participate in the seizure and $10 \%$ to the prosecutorial agency that processes the forfeiture action).

140. See Ainsworth, Seizing the Day, supra note 122.

141. See id.

142. Id.

143. Id. 


\section{Stalemate}

AB 114 sailed through Assembly committees with minimal revisions and was approved by the Assembly, 60-5, on May 27, $1993 .{ }^{144}$ Meanwhile, SB 1158 also passed Senate committees with minimal amendments and was approved by the Senate, 29-0, on June 17, 1993. ${ }^{145}$ However, neither bill was as well received in the other house of the legislature. AB 114 was referred to the Senate Judiciary Committee, which gutted its substantive provisions. ${ }^{146}$ SB 1158 encountered similar resistance in the Assembly Public Safety Committee, which likewise eliminated nuch of the bill's substance. ${ }^{147}$ Neither side was willing to compromise.

Burton, the sponsor of $\mathrm{AB} 114$, worked with Attorney General Lungren and the law enforcement lobby in an effort to reach a compromise. ${ }^{148}$ Burton amended the bill so that forfeiture could proceed without a criminal conviction, and lowered the government's burden of proof from "beyond a reasonable doubt" to "clear and convincing evidence." 149 The amended bill also compromised the allocation formula to allow $65 \%$ of the proceeds to go to law enforcement entities and $10 \%$ to go to prosecutorial agencies, after reimbursement for related expenses. ${ }^{150}$

Lungren, on the other hand, was willing to accept only minimal amendments to SB 1158. The "compromises" reached by Lungren and the law enforcement lobby were meant to address concerns that contesting forfeiture could be economically unfeasible. ${ }^{151}$ One compromise would have added twenty days to the tine property owners had to contest forfeiture; another would have banned seizures of property valued above $\$ 1500 .^{152}$ Ultinately, however, Lungren's hardline approach appeared to backfire. Some Republican Assemblymenbers felt that Lungren, in unilaterally supporting law enforcement, neglected the rights of property owners, a traditional base of Republican support. ${ }^{153}$ Lungren miscalculated in assuming that he could push through SB 1158 on a partisan basis, and failed to acconnt for the increasing opposition to civil asset forfeiture among a

144. A.B. 114 passed the Assembly Public Safety Committee, 5-2, on April 28, 1993, and the Ways \& Means Committee, 20-1, on May 20, 1993. A.B. 114, 1993-1994 Reg. Sess. (Cal. 1994); Complete Bill History, A.B. 114, supra note 110.

145. S.B. 1158 passed the Senate Judiciary Committee, 9-1, on June 2, 1993, and was moved out of the Appropriations Committee without a vote on June 14, 1993. Complete Bill History, S.B. 1158, 1993-1994 Reg. Sess. (Cal 1994), available at http://www.leginfo.ca.gov/pub/93-94/bill/sen/sb_11511200/sb_1158_bill_history (last visited May 1, 2002).

146. See A.B. 114, 1993-1994 Reg. Sess. (Cal. 1993) (as amended July 16, 1993).

147. See S.B. 1158, 1993-1994 Reg. Sess. (Cal. 1993) (as amended Aug. 16, 1993).

148. See Ainsworth, Seizing the Day, supra note 122.

149. A.B. 114, 1993-1994 Reg. Sess. (Cal. 1993) (as amended Sept. 9, 1993).

150. Id. $\$ 18.5(\mathrm{a})(\mathrm{I})$.

151. Asset Forfeiture, CAL. J. WeEkLY, Oct. 18, 1993.

152. Id.

153. Ainsworth, Forfeiting Asset Forfeiture, supra note 120. 
traditionally Republican group: property owners who considered Burton's $\mathrm{AB} 114$ to be more representative of their interests.

One particularly controversial issue slowed down the process of negotiations: whether individuals should be able to use money from seized assets to pay attorneys' fees. Burton's bill allowed forfeiture claimants to retain $\$ 10,000$ for this purpose, ${ }^{154}$ but Lundgren and law enforcement groups objected to the availability of "dirty money" to drug dealers. ${ }^{155} \mathrm{Af}$ ter some contentious exchanges in the press, negotiations halted in September, near the end of the 1993 legislative session. ${ }^{156}$

As the 1993 session ended, those on both sides of the debate speculated as to whether the January 1 sunset date would result in a termination of law enforcement agencies' civil asset forfeiture authority altogether, or merely limit it to its pre-CFA form. ${ }^{157}$ The law enforcement lobby had repeatedly stated that it would rather revert back to the pre-1989 law than accept Burton's proposals. ${ }^{158}$ This insistence rested on the assumption that the operative effect of the sunset date would be to restore the pre-1989 law, even though the pre-1989 law also contained a sunset provision that took effect on January 1, 1989. ${ }^{159}$ Civil libertarians and criminal defense attorneys, supporters of $A B 114$, took the position that even reversion to the pre-CFA law would be a victory because it would require criminal conviction before forfeiture. ${ }^{160}$

Once the 1989 law actually expired, asset forfeiture in California went into limbo. Forfeiture proceedings were challenged and courts in different counties reached different conclusions. In San Mateo, San Diego, and Los Angeles counties, judges ruled that the 1994 sunset provision effectively eliminated forfeiture from state law altogether and that law enforcement agencies were no longer authorized to pursue asset forfeiture. ${ }^{161}$ Judges in Butte, Humboldt and Orange counties held otherwise, concluding that the pre-1989 law resumed as a result of the 1994 sunset date. ${ }^{162}$ Both prosecutors and criminal defense attorneys moved for appeal, ${ }^{163}$ and the split among counties seemed to suggest that the state supreme court would have to settle the issue.

154. Asset Forfeiture, supra note 151.

155. Id.

156. Id. During these exchanges, a spokesman for Lungren likened Burton's provision to "allowing a kidnapper to use the ransom money to pay for a lawyer." $I d$. Law enforcement officials characterized Burton's bill as the "Drug Dealers Protection Act of 1993." Id.

157. See Ainsworth, Compromise Reached, supra note 111, at 3.

158. Asset Forfeiture, supra note 151.

159. Ainsworth, Way Out, supra note 119.

160. Ainsworth, Forfeiting Asset Forfeiture, supra note 120.

161. Ainsworth, Way Out, supra note 119.

162. Id.

163. Id. 


\section{Compromise}

During this legal struggle, law enforcement agencies were faced with a harsh reality: they could not reap the fruits of forfeiture while litigation and appeals proceeded. ${ }^{164}$ Between 1989 and 1994, asset forfeiture had generated over $\$ 150$ million for law enforcement agencies. ${ }^{165}$ While lawyers battled in the courts, law enforcement agencies were deprived of this revenue stream, facing the stark reality that they might permanently lose their forfeiture authority. ${ }^{166}$ Confronted by this possibility, the law enforcement lobby apparently became more willing to compromise. However, it soon became evident that there was one area in which the law enforceinent lobby was not willing to compromise: the allocation of revenues generated.

When the legislature resumed business in January 1994, the law enforcement lobby faced the threat of losing forfeiture power entirely; it could no longer take the stance that virtually anything would be preferable to AB 114. In March, a Conference Committee consisting of three Asseinblymembers, including Burton, and three Senators, including Maddy, convened to reconcile the two previously tabled proposals, AB 114 and SB $1158 .{ }^{167}$

Nearly five months later, a newly amended version of $\mathrm{AB} 114$ emerged froin the Conference Committee. The bill that had once stalled in the committee was given a new life; both the Assembly and the Senate quickly approved the bill unanimously. ${ }^{168}$ An urgency clause was adopted so as to enable the bill to take effect upon approval by the Governor. ${ }^{169}$ Governor Pete Wilson approved the measure and the bill went into effect on August 19, 1994. ${ }^{170}$

As a consequence of the negotiations, California's drug forfeiture law has inore roots in AB 114 than in SB 1158, including its substantial procedural protections, express prohibitions on conditioning prosecutor or law enforcement salary on forfeiture achieveinents, and a ban on putting forfeited property, such as vehicles, into service to be used directly by law enforcement agencies. ${ }^{171}$ It does not, however, reallocate the revenue from seizure proceeds or otherwise take money out of law enforcement coffers; rather, it reimburses government agencies for all forfeiture-related expenses, and then directs $65 \%$ of the remaining

164. John Pope, Expiration of Seizure Law Stymies Police; Finances: Narcotics Officers and Prosecutors Struggle to Operate Without a Valuable-and Profitable-Tool, New Legislation Is in Limbo, L.A. TIMES, Mar. 3, 1994, at J3.

165. Id.

166. Id.

167. Complete Bill History, A.B. 114, supra note 110.

168. Id.

169. Id.

170. Id.

171. Cal. Health \& Safety Code $§ 11469$ (West 2001). 
feiture-related expenses, and then directs $65 \%$ of the remaining proceeds to law enforcement agencies that participated in the seizure and $10 \%$ to the prosecutorial agencies that process the forfeiture action. ${ }^{172}$

The drug-related asset forfeiture statute created several procedural protections, ${ }^{173}$ including many that were proposed in the original version of $\mathrm{AB} 114 .{ }^{174}$ For one, real property subject to forfeiture may not be seized until the prosecution demonstrates at a hearing that: (1) probable cause exists for the forfeiture of the property and (2) exigent circumstances exist that make seizure necessary to preserve the property pending the outcome of the forfeiture proceedings. ${ }^{175}$ It also requires the district attorney or the Attorney General to file a petition for forfeiture as soon as practicable or within one year of seizure, whichever is earlier. ${ }^{176}$ Further, a judgment of forfeiture requires an underlying criminal conviction; ${ }^{177}$ and, after conviction, forfeiture defendants are entitled to a jury-finding that the assets are forfeitable beyond a reasonable doubt. ${ }^{178}$ Finally, the drug forfeiture law also includes protections for innocent owners, which prevent the seizure of property of third-party owners who were unaware that their property was being used for an illegal purpose. ${ }^{179}$

However, the drug-related forfeiture statute does reflect some concessions made in the Conference Committee. Unlike the original proposal, the statute requires fewer procedural protections in cases where the forfeited property is personal property valued under $\$ 25,000 .{ }^{180}$ Also, the government is not required to reimburse successful claimants for attorneys' fees. ${ }^{181}$ Lastly, and most importantly, under the new statute, law enforcement agencies continue to receive the bulk of the proceeds. ${ }^{182}$ After distribution to any bona fide innocent owners and reimbursement of expenses for participating agencies, $65 \%$ of the remaining proceeds go to participating law enforcement agencies, $10 \%$ to the prosecutorial agency that processed the forfeiture action, and $24 \%$ to the General Fund. ${ }^{183}$

\footnotetext{
172. §11469(1)-(2).

173. See $\$ 11488.4$ (detailing procedural requirements in a state forfeiture action).

174. See supra notes $126-30$ and accompanying text.

175. Cal. Health \& SAFETY CoDE $\S 11471$ (e) (West 2001).

176. $\S 11488.4(\mathrm{a})$.

177. $\$ 11488.4(\mathbf{i})(3)$.

178. $\$ 11488.4(\mathrm{i})(1),(3)$.

179. $\$ 11488.6(\mathrm{a})$.

180. $\S 11488.4(\mathrm{j})$. The bill originally introduced by Burton excepted the criminal conviction requirement only if the defendant had intentionally fled the jurisdiction, died, or had actual knowledge or played a role in committing an offense that made the property subject to forfeiture. A.B. 114, supra note 126.

181. The original Burton proposal contained a provision for such recovery. A.B. 114, supra note 126.

182. See Cal. Health \& SAFETy CODE $§ 11489$ (West 2001).

183. Id. $1 \%$ of the proceeds goes to training prosecutors and law enforcement officers in "ethics and the proper use" of forfeiture laws. Id. The bill originally introduced by Burton transferred all
} 
In sum, a combination of fortuitous timing and effective coalitionbuilding resulted in significant procedural reforms of the forfeiture process; but, as much as law enforcement groups were pressed to compromise, they did not yield on the distribution scheme. The financial incentives underlying civil asset forfeiture for law enforcement agencies remained $\mathrm{m}$ tact.

\section{Lessons From the Legislative Process of $A B 114$}

Several important lessons can be drawn from California's new drug forfeiture law. Reformers took advantage of publicity about abuses of civil asset forfeiture, as well as the auspicious timing of California's sunset provision, to force law enforcement groups to compromise on reform. However, the legislative process also demonstrates how strongly law enforcement interests could resist the reallocation of revenue from civil asset forfeiture.

Burton's reform effort came at a time when the potential for abuse of forfeiture authority was publicly known and feared. The 1992 killing of Donald Scott at the hands of law enforcement officers received negative press coverage ${ }^{184}$ At the same time, law enforcement interests overreached by introducing SB 1158, which would have expanded their forfeiture power. ${ }^{185}$ Viewed in light of the Scott incident, law enforcement agencies appeared simply hungry for more authority and insensitive to public concerns over abuse of power.

Furthermore, Burton brought together an effective, albeit uncommon, coalition of supporters for $A B 114$. The usual match between law enforcement groups and criminal defense advocates often made the choice too simplistic for both the public and legislators, and led to a presumption typical in public safety legislation that the police are the "good guys." By putting the interest of organized property-owners at the forefront of the bill's consideration, however, Burton turned the usual presumption on its head. The bill presented reform as enhancing the rights of ordinary citizens against an abusive police force. Also, by entangling the interest of wellorganized property interest groups, Burton was able to use both their public reputation and their political pull. Republican legislators were forced to choose between two of their dominant constituencies, and many legislators sided with and voted to approve Burton's bill.

proceeds, after distribution to bona fide innocent owners, to the state General Fund, and designated up to $5 \%$ to the Restitution Fund, up to $5 \%$ to county mental health programs, and a minimum of $10 \%$ to drug abuse prevention and education programs. A.B. 114, supra note 126.

184. See, e.g., Paul Craig Roberts, The Spiraling Gestapo State Is Among Us: Bureaucrats and Forfeiture Laws Are Taking Away Our Liberty, L.A. TIMES, Aug. 29, 1993, at 5.

185. Ainsworth, Seizing the Day, supra note 122. 
However, given the weakened bargaining position of the law enforcement lobby in light of the Scott incident and the SB 1158 backlash, one should question why Burton and his coalition were unable to push through changes affecting the distribution of revenue from civil asset forfeiture. Before the political stalemate in the 1993 legislative session, Burton had already conceded procedural safeguards. ${ }^{186}$ The final version of $A B$ 114 produced by the Conference Committee suggests that the law enforcement camp was willing to acquiesce to very high procedural standards in order to preserve the allocation formula that maintained its financial stake in the process: maintenance of the CFA distribution scheme that allocated over $75 \%$ of forfeiture proceeds to participating law enforcement agencies. ${ }^{187}$

More importantly, given that the financial benefits of civil asset forfeiture remain, law enforcement agencies now have an incentive to find ways around the new procedural protections to the extent those protections slow the revenue stream. As will be seen in the next Part, there are several loopholes that enable such circumvention. Had the new law restricted the ability of law enforcement to benefit financially from civil asset forfeiture, these loopholes likely would not be as popular as they are today.

\section{LoOpholes in CALIFornia's 1994 Drug ForfeItuRe LAW}

The 1994 law provides California property owners with many procedural protections in forfeiture proceedings that other states have only recently achieved. ${ }^{188}$ However, several loopholes enable law enforcement agencies to circumvent the procedural protections. Arguably such circumvention techniques are especially appealing to law enforcement agencies

186. See A.B. 114, supra note 149 (allowing the government to proceed in forfeiture without first securing an underlying criminal conviction and lowering government's burden to clear and convincing evidence).

187. See supra note 15 .

188. In November 2000, citizens in Oregon and Utah approved ballot initiatives to change their state forfeiture laws. The Oregon initiative amended the state constitution so as to require criminal conviction before property can be seized. 2001 OR. LAws Ch. 780 (H.B. 2429). The Utah initiative also added procedural protections for defendants in forfeiture proceedings, including rights to jury trial and counsel, hardship exemptions, and the right for successful defendants to sue law enforcement agencies for reasonable fees. UTAH CODE ANN. \$§ 24-1-1 to 24-1-16 (2001). ln 2001, the Washington state legislature passed SHB 1995, which made only minor procedural changes to the state's civil forfeiture laws and shifted the burden of proof to the prosecution to establish by a preponderance of the evidence that the property is forfeitable. WASH. REv. CODE ANN. $\S 69.50 .595$ (West 2001). Given the scant modifications achieved by legislation, a ballot initiative is now pending that would require a substantial relationship between the forfeited property and the crime for which the owner has been convicted, and would subject the seizing agency to liability if property is damaged while forfeiture proceedings are pending. Text of Washington Initiative 1-784, The Innocent Property Owners Protection Initiative, available at www.libertyinitiatives.org (last visited on May 1, 2002). 
given the continued economic rewards of asset forfeiture. ${ }^{189}$ In short, law enforcement agencies have a financial incentive to find and exploit loopholes so as to minimize the impact of procedural obstacles to the financial gain of forfeiture. This Part will describe two such loopholes used by law enforcement agencies to undermine the 1994 procedural reforms. Part V will present reform proposals designed to address these loopholes and, more importantly, reduce law enforcement agencies' imcentives to abuse civil asset forfeiture for financial gain.

\section{A. The Local Loophole: Horton v. City of Oakland}

One loophole in the 1994 law, first spelled out by a California appellate court in the case of Horton $v$. City of Oakland, allows municipalities to develop their own forfeiture ordinances so long as they do not explicitly conflict with state law and, in some cases, even if they do. ${ }^{190}$ Horton opens the door for law enforcement agencies to pursue forfeiture under local ordinances that, like the Oakland ordinance at issue in Horton, offer fewer procedural protections than the 1994 state law. ${ }^{191}$ While the Oakland ordinance reduces procedural requirements, its treatınent of profits is similar to the state's: proceeds are split between police and prosecutors. ${ }^{192}$ The Horton loophole demonstrates the insufficiency of procedural protection in changing law enforcement agencies' forfeiture practices; as long as the monetary incentives exist, law enforcement agencies will find ways to avoid the procedural hurdles.

In Horton, two defendants challenged an Oakland City ordinance that authorized local police to seize vehicles involved in solicitation of prostitution or acquisition of controlled substances, argning that state law preempted the ordinance. ${ }^{193}$ The Oakland ordinance, in contrast to state law, did not require a conviction for the underlying criminal offense, did not include an innocent-owner defense, did not contain a community-property exemption, and only required the prosecution to prove the alleged connection to criminal activity by a preponderance-of-the-evidence standard. ${ }^{194}$

At the outset, the Court of Appeal described its two-step analytical approach to the preemption question. It would first determine whether the ordinance actually conflicted with state law. ${ }^{195}$ If it found a conflict, it

189. See Blumenson \& Nilsen, supra note 2, at $94-95$ (describing, as a product of the economic incentives of forfeiture, the onslaught of "multijurisdictional" task forces that circumvent more stringent state laws by evoking federal jurisdiction).

190. 98 Cal. Rptr. 2d 371 (Cal. Ct. App. 2000).

191. See id. at $375 \mathrm{nn} .8,9$ (contrasting the procedural requirements of forfeiture under state law and under the Oakland ordinance).

192. Id. at 375 n.9.

193. Id. at 372 .

194. Id. at 375 n.9.

195. Id. at 373 . 
would then review the applicability of the "home rule" doctrine in the California State Constitution:

Article XI, section 5, the "home rule" doctrine, reserves to charter cities [such as Oakland] the right to adopt and enforce ordinances that conflict with general state laws, provided the subject of the regulation is a "municipal affair" rather than one of "statewide concern." 196

The Horton court upheld the ordinance because it did not find a conflict between the Oakland ordinance and state law. ${ }^{197}$ The court interpreted the new law to be silent with regard to drug buyers, and found that the Oakland ordinance covering buyers addresses an area "untouched by statewide legislation." 198 The court rejected the defendants' argument that the comprehensive scheme of state forfeiture laws demonstrated a legislative intent that drug asset forfeiture laws be uniform throughout the state, thus implicitly preempting the Oakland ordinance. ${ }^{199}$ Instead, the court concluded that the 1994 statute did not contain a sufficiently clear indication that the legislature intended state law to exclude local regulation of forfeiture, and held that the Oakland ordinance did not conflict with the 1994 law explicitly or implicitly. ${ }^{200}$ "If the Legislature wishes to preempt local forfeiture ordinances of this kind," concluded the court, "it must express that intention by enacting appropriate legislation."201 Finally, the court declined to apply the "home rule" doctrine because the case was resolved by the conflict analysis. ${ }^{202}$ The California Supreme Court subsequently denied review, ${ }^{203}$ so the principles stated in Horton apply throughout trial courts in California. ${ }^{204}$

Horton is problematic in several respects. The court held that that the Oakland ordinance was not preempted because (1) it did not regulate the particular conduct covered by state $\mathrm{law}^{205}$ and (2) the legislature did not expressly state its intention to preempt local ordinances. ${ }^{206}$ This holding may encourage local authorities to circumvent state procedures by adopting ordinances like Oakland's that trigger forfeiture authority with a slight

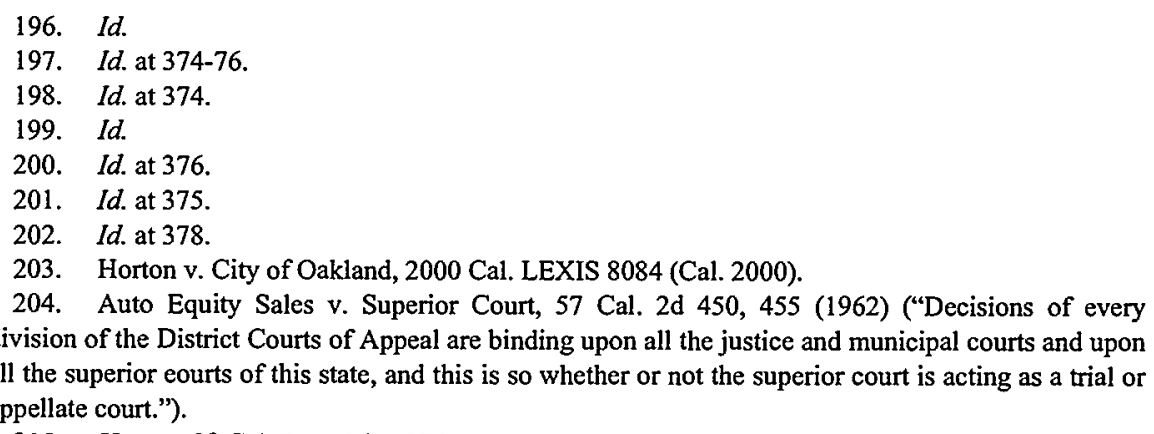

205. Horton, 98 Cal. Rptr. $2 \mathrm{~d}$ at 374.

206. Id. at 376 . 
variation of a crime covered by state law or with a crime not covered by the state forfeiture law, while providing substantially less procedural protection than state law. It appears that several cities are trying to do just that. ${ }^{207}$ According to Oakland City Attorney Pelayo Llannas, nearly a dozen California cities contacted the City of Oakland after Horton was decided to ask for advice on how to go about enacting similar forfeiture ordinances. ${ }^{208}$

Furthermore, while the Court of Appeal in Horton did not base its holding on the "home rule" doctrine, it also did not foreclose the possibility that, even if a conflict did exist between municipal and state law, a local ordinance might prevail in a charter city if it addressed a matter of "municipal concern." The court's statement on the potential applicability of the "home rule" doctrine to forfeiture suggests that charter-city ordinances may openly conflict with state procedures. ${ }^{209}$ This may hold true even in forfeiture cases based on crimes covered by state law, because there is no express statement by the state legislature that drug-related forfeiture

is a matter of statewide concern. ${ }^{210}$ There are currently over fifty charter cities in California, including urban areas such as Oakland, Los Angeles, Sacramento, and San Francisco. ${ }^{211}$ These cities could enact, for exainple, an asset forfeiture ordinance that permits seizure of a car suspected of facilitating drug sales, but that does not require a criminal conviction for the underlying drug sale or the owner's actual knowledge of and consent to the illegal use of the car, and sets the prosecuting agency's burden of proof at a preponderance-of-the-evidence standard. Such an ordinance would regulate an area that is covered by state law, the forfeiture of vehicles used to facilitate drug sales, ${ }^{212}$ but would conflict explicitly with state procedural requirements for a criminal conviction: proof beyond a reasonable doubt that the property is subject to forfeiture, and proof of owner's actual knowledge and consent. ${ }^{213}$ Yet the Horton court's interpretation of the "home rule" doctrine pernits this kind of outright contradiction of state law if the

207. Sacramento and Los Angeles have already enacted measures similar to Oakland's. Sonia Giordani, Oakland Seizes the Day, THE RECORDER, July 28, 2000, at 1. Lawmakers in San Francisco, on the other hand, considered but rejected a similar seizure law after concluding that it was unconstitutional. Associated Press, State Supreme Court Won't Review Vehicle Seizure Law, L.A. TMMEs, Oct. 19, 2000, at A36.

208. Associated Press, supra note 207.

209. Horton, 98 Cal. Rptr. 2d at 373 ("[B]ecause Oakland is a charter city, an additional constitutional provision can come into play ... the "home rule" doctrine.").

210. See id. at 373-74.

211. For a complete listing of charter cities and city charters, see League of California Cities, available at www.cacities.org/doc.asp?id $=3520$ (last visited May 1,2002). A charter city is a city that adopts a charter according to the guildines of the California Constitution. CAL. ConST. art. XI, $\S 3$.

212. Cal. Health \& SafeTy Code $\$ 11470(\mathrm{e})$ (West 2001).

213. §11438.4(i)(1), (3); § 11488.5(e). 
chartered cities successfully argue that the forfeiture is a "municipal affair" rather than a "statewide concern." 114

Moreover, the Court of Appeal left open the possibility of duplicative forfeiture proceedings. In footnote ten of its opinion, the court addressed a scenario presented by the defendants in which a person using a vehicle to purchase a large quantity of drugs in Oakland would be subject to both the Oakland ordinance and state law, two sets of laws with conflicting forfeiture procedures. ${ }^{215}$ The court dismissed the scenario as hypothetical, but not before stating that '[b]ecause appellants' hypothetical presupposes the violation of two separate enactments directed at different behaviors, there is no inherent conflict in the person being subject to two different possible penalties."216 Again, this dictum suggests that prosecuting agencies can choose to bring the forfeiture action under the more lenient set of forfeiture rules. Worse yet, it may give agencies a second shot if the proceeding under the first set of rules does not result in forfeiture.

Horton undercuts California's efforts to reform civil asset forfeitures by allowing chartered cities to disregard the procedural protections of the 1994 law. Law enforcement agencies motivated by the financial rewards of civil asset forfeiture have the option of pursuing forfeiture under a local rule, such as the one upheld in Horton, that gives these agencies the proceeds of forfeiture without the added procedural requirements of state law. In order to prevent distortion of law enforcement objectives and abuse of the forfeiture process, reform needs to do more than establish procedural rules that can be circumvented; reform must alter the underlying economic incentives for law enforcement agencies.

\section{B. The Federal Loophole: Federal Adoption}

Similar to the Horton rule, which allows law enforcement agencies to use local ordinances to circumvent stricter state laws, federal adoption provides yet another loophole for law enforcement agencies to undercut state level procedural reform. Federal adoption is particularly seductive to law enforcement groups because it is so lucrative: the federal government disbursed over $\$ 37$ million to California law enforcement agencies in the $1997-98$ fiscal year and over $\$ 32$ million in 1998-99. ${ }^{217}$

214. See Horton, $98 \mathrm{Cal}$. Rptr. 2d at 373. The California Supreme Court has held that the inquiry into whether an area of law if of municipal or statewide concern would only be conducted if a clear conflict exists between local and state law. Johnson v. Bradley, 4 Cal. 4th 389, 399 (1992). In the event that a court finds a conflict, it is then up to the court to mediate the dispute between the charter city and the state; in other words, the court will determine whether an area of concern is more municipal than statewide or vice vcrsa. See id., at 399-400.

215. Horton, 98 Cal. Rptr. $2 d$ at 376 n.10.

216. Id.

217. Senate Committee on Public Safety, Analysis of S.B. 1866 (Apr. 25, 2000), available at http://www.leginfo.ca.gov/pub/99-00/bill/sen/sb_185I-1900/sb_1866_cfa_20000425_I55959_sen_ comm.html (last visited May I, 2002). 
The federal forfeiture statutes allow the U.S. Department of Justice to "adopt" local and state forfeitures and distribute up to $80 \%$ of the proceeds back to local and state law enforcement agencies. ${ }^{218}$ Federal adoption is available even when the particular seizure is accomplished exclusively by state or local agencies, as long as the crime giving rise to the seizure violates federal law, as do most drug offenses. ${ }^{219}$ Turning state forfeitures over to the federal government for distribution of proceeds enables local and state law enforcement agencies to circumvent state distribution schemes and stricter state forfeiture procedural requirements. ${ }^{220}$ Thus, federal adoption allows law enforcement agencies to reap the financial rewards of forfeiture with minimal procedural hurdles and political accountability, ${ }^{221}$ and again demonstrates that civil asset forfeiture reform must address the process's inherent defect: law enforcement agencies' economic incentives.

From the perspective of state law enforcement, there are at least three financial advantages to federal adoption. First, the United States Attorney General rather than local prosecutors prosecute the forfeiture proceeding. ${ }^{222}$ Second, through federal adoption, law enforcement agencies can circumvent the procedural protections established under California's 1994 law. ${ }^{223}$ For example, whereas a California prosecuting agency needs both a criminal conviction and a showing beyond a reasonable doubt that the property is forfeitable, a federal prosecutor only must demonstrate the forfeitability of the property by a preponderance-of-the-evidence standard, and need not even charge the property owner with a crime. ${ }^{224}$ The reduced federal standards suggest a greater number of successful seizures, which in turn would generate increased revenues for state and local law enforcement. Third, while California law designates $65 \%$ of forfeiture proceeds, plus forfeiturerelated expenses, to participating law enforcement agencies, the same participating state agencies receive up to $80 \%$ of the total proceeds of a successful federally-adopted forfeiture action. ${ }^{225}$ Moreover, the Justice Department requires that funds distributed through federal adoption be used exclusively for law enforcement purposes. ${ }^{226}$ Thus, in order to fully address the financial incentives of civil asset forfeiture, California must not only alter the forfeiture distribution scheme under state law, but must also

218. Blumenson \& Nilsen, supra note 2, at 52 .

219. Id. at 51 n.64.

220. Id. at 54.

221. Hadaway, supra note 8, at 93-94.

222. Blumenson \& Nilsen, supra note 2, at 54, n.67.

223. Karen Dillon, Police, Federal Agencies Resist Change, Kansas City StaR, May 22, 2000, at Al.

224. See Cal. Health \& SafeTy Code $\$ 11488.4(i)$ (West 2001); Forfeiture: A Welcome Reform, L.A. Tmies, Apr. 23, 2000 , at M4.

225. See Cal. Health \& SafeTy CODE $\$ 11489$ (West 2001); Blumenson \& Nilsen, supra note 2, at 52 .

226. Blumenson \& Nilsen, supra note 2, at 51. 
limit law enforcement agencies' use of federal adoption. California's past efforts to address federal adoption and a new proposal will be discussed in Part V.

Both federal adoption and local ordinances offer state law enforcement agencies means to circumvent California's 1994 procedural reforms. These loopholes demonstrate that until the economics of forfeiture are adjusted, procedural protections will not change the practices or mitigate the abuses of the forfeiture process at the hands of its law enforcement beneficiaries. The following Part presents reform proposals designed to address these particular loopholes and, more importantly, to reduce law enforcement agencies' problematic financial stake in civil asset forfeiture.

\section{$\mathrm{V}$ \\ REFORM PROPOSALS}

Beginning with the assumption that California's drug forfeiture laws will not be completely eliminated in the near future, this Comment argues that reformulation of the financial construct of the civil asset forfeiture system is a necessary prerequisite to successful reform. As long as law enforcement agencies profit financially from civil asset forfeiture, the problems discussed in Part II will persist: law enforcement agencies motivated by the forfeiture money will distort law enforcement objectives, abuse the forfeiture process, and evade political accountability. Reform, therefore, must address not only the effects of these incentives-law enforcement evasion and infringement of procedural rights-but also the incentives themselves.

The reform proposals presented here draw from experiences in California and other states, and aim to reduce the harsh effects and unjust results of civil asset forfeiture on two fronts. First, and most importantly, this Comment suggests taking aim at the financial incentives that drive the law enforcement agencies to distort policies and abuse forfeiture practices. Second, and more indirectly, proposals are offered to limit law enforcement groups' circumvention of existing California forfeiture procedures.

\section{A. Altering the Financial Incentives: Changing California's Current Forfeiture Allocation Formula}

The inherent defect of civil asset forfeiture lies in its financial incentives. Because it rewards law enforcement agencies financially in proportion to the value of assets seized, civil asset forfeiture distorts law enforcement objectives, encouraging agencies to focus on maximum financial gain rather than criminal deterrence. ${ }^{227}$ Additionally, by allowing

227. Id. at 56. See also discussion in Part II. 
agencies to self-finance, civil asset forfeiture severs political accountability. ${ }^{228}$

Currently, California law allocates $65 \%$ of forfeiture proceeds, after costs, to state and local law enforcement agencies that participated in the forfeiture. ${ }^{229}$ One way to reduce civil asset forfeiture's financial incentives is for the state legislature, which determines the allocation of forfeiture proceeds, to sever the economic link by directing forfeiture assets away from the law enforcement agencies that seize them. The idea of reallocation is not new. $\mathrm{AB} 114$, the bill that ultimately became California's civil asset forfeiture law in 1994, initially contained a provision that directed all proceeds of forfeiture to the state's General Fund. ${ }^{230}$ As previously discussed, however, the reallocation provision in $\mathrm{AB} 114$ was deleted as part of the compromise in the Conference Committee, and was not contained in the final version of the bill that was signed into law. ${ }^{231}$

Although California's past attempts at reallocation demonstrate the power of the law enforcement lobby to resist such a proposal, choosing the right allies and tailoring a proposal to the current political environment may offer reformers better success. This Part will recommend a proposal for directing civil asset forfeiture proceeds to public schools in light of California's present political and economic situation.

\section{Redirecting Civil Asset Forfeiture Proceeds to Public Schools}

The allure of designating forfeiture funds to public schools is obvious. The need to educate the state's children is about as non-controversial as a political issue can be. Although there likely will be soine political resistance, designating public schools as the beneficiary of a reallocation scheine has three distinct political advantages that will help the proposal to succeed.

First, by avoiding the traditional dichotomy between law enforcement and crimimal defense interests, this proposal can defeat or at least initigate the usual presumption that law enforcement represents the "good guy" in the contest against "soft on drugs" criminal advocates. ${ }^{232}$ The proposal would be backed by teachers and parents rather than the criminal defense interests that traditionally advocate for changes in civil forfeiture. This proposal would appeal to the public and legislators because they are more likely to empathize with and be persuaded by teachers and school children; a similar empathy with property owners enabled the success of the 1994 refornus. The appeal of this proposal would be hard to resist, especially in

228. Blumenson \& Nilsen, supra note 2, at 84.

229. CAL. Health \& SafETy CODE $\$ 11489$ (2001) (West 2001).

230. A.B. 114, supra note 126.

231. See Ainsworth, Compromise Reached, supra note 111.

232. Blumenson \& Nilsen, supra note 2, at 39. 
light of the kind of cut-backs (on class-size reduction programs, on school bus repairs, on heating for classrooms) that must be made in response to continued budget cuts. ${ }^{233}$ The effects of this reallocation proposal would be felt in schools in every electoral district.

Second, the proposal eviscerates the law enforcement lobby's defense that civil asset forfeiture, apart from its financial benefits for law enforcement agencies, is an effective and necessary tool in the war on drugs because forfeiture undermines the economic support of the drug trade. ${ }^{234}$ Allocating proceeds to a non-law enforcement area neither reduces the police's authority nor increases its burden in civil asset forfeiture proceedings. Law enforcement agencies would be reimbursed for civil asset forfeiture-related expenditures; the proposal would simply direct the remaining proceeds (the profits) for use by public schools. Law enforcement objections to the allocation of forfeiture funds to public schools, then, would have to provide an explanation of why law enforcement agencies deserve or need the proceeds more than the public schools.

Third, and perhaps most importantly, such a proposal would galvanize an interest group other than criminal defense advocates. By designating money for education, this proposal would exploit both the strength and reputation of the education lobby. Educators could use their political clout to support the reallocation of civil asset forfeiture funds. Once this is achieved at the state level, the same educators would have an interest in preventing the circumvention of the state allocation formula through federal adoption. The education lobby's interest, unlike that of the law enforcement lobby, would be to close the federal adoption loophole so that forfeiture proceeds would be distributed to public schools under the state allocation scheme rather than to law enforcement agencies under the federal adoption scheme.

Although public education is probably the best single candidate to receive civil asset forfeiture proceeds, such a reallocation does raise some concerns. Once civil asset forfeiture money is committed to public education, it would be extremely difficult to divert the funds later to other worthwhile causes such as drug treatinent programs. Just as it may serve as a formidable political foe for the law enforcement lobby, the education lobby would be equally effective against other competitors. This implicates a problem similar to law enforcement groups' current control; any powerful group that has a financial stake in civil asset forfeiture could use its political weight to limit changes that would affect funding, including reallocation as well as reform proposals that make the process more costly and therefore less profitable.

233. Felicia Cousart Matlosz, Schools Gulp on Returning Money: Millions of Dollars Already Budgeted May Have to Be Given Back to the State, FrESNo BEE, Dec. 9, 2001, at Al.

234. Blumenson \& Nilsen, supra note 2, at 44-45. 
However, these concerns are theoretical at best. Teachers and other public education groups are not directly connected to the implementation of the civil asset forfeiture process. Currently, law enforcement agencies control the means to their economic ends, and police seize with these financial benefits in mind. ${ }^{235}$ Teachers, however, do not exercise such control over the means. Any effort on their part to dictate the civil asset forfeiture process, and consequently the conduct of police and prosecutors, likely would be checked by law enforcement advocates.

\section{The California Budget Situation: An Impetus for Reallocation}

California's current economic difficulty, triggered by the 2000 energy crisis, suggests a need to look for new revenue streams. ${ }^{236}$ If properly informed about the benefits of reallocating civil asset forfeiture revenues, California taxpayers and voters might rally behind the diversion in order to reduce deficit spending and avoid increased taxes.

In an effort to tide the rising cost of energy for consumers, the state tapped into the General Fund in order to purchase energy from other states. ${ }^{237}$ The state spent an estimated $\$ 50$ million per day of General Fund dollars during the winter of 2000-01 and approximately $\$ 90$ million per day during the summer of 2001 to meet demands for electric power. ${ }^{238}$ Severe budget cuts resulted. ${ }^{239}$ Governor Davis's revised budget in May 2001 cut $\$ 300$ million earmarked for local governments, $\$ 50$ million from the Department of Corrections, and $\$ 90$ million from beach clean-up programs. ${ }^{240}$

By October 2001, after an additional drop-off in state revenue, a downturn in the stock market following September 11th, and an increase in demands for social services, estimates of the state deficit ranged from $\$ 8$ billion to $\$ 14$ billion, not including the $\$ 6$ billion that was borrowed from the General Fund to defray energy costs. ${ }^{241}$ Governor Davis ordered a hiring freeze and ordered state agencies to trim $\$ 150$ million to save $\$ 500$

235. See id. at 56,68 .

236. In 2000, two of California's energy providers became insolvent, causing a sharp increase in consumer energy costs. Crisis Ruins State's Credit Rating, Modesro BeE, Apr. 30, 2001, at B6. In January 2001, the state began to purchase power for utility customers with money from the state's Gcneral Fund, causing a ripple effect that ultimately necessitated severe budget cuts in state programs, including public education. Ed Mendel, State Gets $\$ 4.3$ Billion Loan to Buy Energy, SAN Diego UNION-TRIBUNE, June 27, 2001, at A3.

237. Crisis Ruins State's Credit Rating, Modesto BEE, Apr. 30, 2001, at B6.

238. Hole in the Treasury, L.A. Trmes, Apr. 27, 2001, at B8.

239. Julie Tamaki, Davis' Revised Budget Digs Heavily Into Reserves, L.A. Times, May 15, 2001, at B1.

240. Id.

241. Julie Tamaki, State Deficit May Reach \$14 Billion, Davis Says; Budget: Democratic Lowmakers Urge Suspending Tax Cuts; Republicans Oppose Tax Hikes, L.A. Times, Oct. 25, 2001, at 8. 
million. ${ }^{242}$ Governor Davis then recalled $\$ 843.5$ million designated for lower-education in order to balance the budget. ${ }^{243}$ Cuts were proposed for before-and-after-school care, class-size reduction, Healthy Start, and other programs to which districts had already committed money. ${ }^{244}$ Similar cuts are expected in the next fiscal year, along with possible tax increases. ${ }^{245}$

The California budget crisis may make the public and legislature receptive to a proposal that would direct proceeds from state civil asset forfeitures into the General Fund. Civil asset forfeiture would still be available to prosecutors and police, and they could still be reimbursed for the costs of civil asset forfeiture activities; they simply would not receive an additional $65 \%$ of the remaining proceeds. At a time when many state programs are being cut and the state budget is in disarray, legislators should consider whether continuing the existing civil asset forfeiture allocation scheme is as important as averting higher taxes.

\section{The Final Impact}

Reallocating civil asset forfeiture revenues from law enforcement agencies to education would accomplish several goals. First, it would alter the objectives and motivations of law enforcement agencies in conducting civil asset forfeiture. Additionally, law enforcement agencies would be subject to political accountability through the budget process. Meanwhile, public schools would benefit from additional funding and the state's General Fund could be used to address other pressing needs. Lastly, while it is true that any powerful interest group would have a dedicated interest in ensuring maximum revenue from a source as profitable as civil asset forfeiture, teachers are less able to abuse civil asset forfeiture for financial ends than are law enforcement agencies because teachers do not control the forfeiture process. Thus, this proposal would reduce the incentives for law enforcement agencies to abuse civil asset forfeiture while benefiting schoolchildren as well as taxpayers.

However, it should be noted that this proposal cannot work in isolation. Loopholes still exist in California's civil asset forfeiture laws, including the Horton rule and federal adoption. While California could close the Horton loophole, there is less the state can do about federal adoption; thus, it is important to note that this proposal could actually encourage even broader use of federal adoption, which currently remits $80 \%$ of civil asset forfeiture proceeds to state and local law enforcement agencies. ${ }^{246}$ Ideally, Congress would adopt a policy similar to the one proposed here to more

242. Andrew LaMar, California Governor Enacts Hiring Freeze, Orders $\$ 150$ Million Cutback, CONTRA Costa Times, Oct. 24, 2001.

243. Matlosz, supra note 233.

244. Id.

245. See id; Tamaki, supra note 241 , at 8 .

246. Blumenson \& Nilsen, supra note 2, at 52. 
appropriately allocate civil asset forfeiture revenues. Until that happens, states must make efforts to curtail the use of federal adoption, as well as the Horton loophole. Proposals for addressing these loopholes are discussed in the next Section.

\section{B. Curbing Use of Local and Federal Law}

The proposal to redistribute civil asset forfeiture proceeds to public schools aims to reduce law enforcement agencies' financial incentives to pursue civil asset forfeiture at the expense of criminal deterrence and individual due process. In order for the proposal to have its full impact, however, loopholes that enable law enforcement agencies to evade state law must be closed. As discussed in Part IV, law enforcement agencies have circumvented procedural protections of California's civil asset forfeiture laws ${ }^{247}$ by using local ordinances, as permitted by Horton, and by turning over forfeitures to the federal government by way of federal adoption. The use of local ordinances and federal adoption can similarly undermine a new civil asset forfeiture distribution scheme. These two loopholes must be closed in order to effectively minimize the financial incentives of civil asset forfeiture for law enforcement agencies.

\section{Past Efforts to Curb Circumvention}

The good news in curbing circumvention by closing the Horton and the federal adoption loopholes is that it is clear what needs to be done. The bad news is that the California legislature's attempts on both fronts have not been successful. This Comment argues, however, that the proposal to redirect civil asset forfeiture proceeds to public schools will go a long way in overcoming the law enforcement lobby's influence and eventually will bring about success in closing these two loopholes.

Although the Horton court declined to find preemption of the Oakland ordinance by state law, it clearly demonstrated how such preemption could be accomplished: an express declaration from the legislature that drugrelated civil asset forfeiture is a matter of statewide concern, and that state law is to be exclusive of any local ordinance or regulation. ${ }^{248}$ Express language would also address the potential application of the "home rule" doctrine to allow conflicting local rules by making clear that drug-related civil asset forfeiture is a matter of "statewide concern."249

In 1999, Assemblymember Herb Wesson attempted such an express declaration through an amendment to $\mathrm{AB} 662,{ }^{250}$ a bill that would have

247. Cal. Health \& Safety Code $§ \S 11469-95$.

248. Horton v. City of Oakland, 98 Cal. Rptr. 2d 371, 375-76 (Cal. Ct. App. 2000).

249. Id. at 373 .

250. Complete Bill History, A.B. 662, 1999-2000 Reg. Sess. (Cal. 2000). 
extended civil asset forfeiture procedures to non-drug-related crimes. ${ }^{251}$ One week before the bill was enrolled to the Governor, the bill was amended to include the following declaration of legislative intent:

The procedures and provisions of state law relating to seizure and forfeiture proceeds from, and property used in the commission of, criminal offenses, including controlled substance and prostitution offenses, shall preempt and be exclusive of all local ordinances and regulations relating to the seizures and forfeitures. ${ }^{252}$

The bill was vetoed by Governor Gray Davis, who did not "support this bill's broad attack on local forfeiture ordinances" and considered it inappropriate "for the State to take away the tools from Oakland, Sacramento, and other cities considering the adoption of similar ordinances without a more careful analysis of the amount of discretion which should be left to cities to craft their own remedies in response to local conditions."253

Efforts to close the federal adoption loophole met a similar fate. In February 2000, California State Senator John Vasconcellos introduced SB $1866 .^{254}$ The bill sought to close the federal adoption loophole by prohibiting state and local agencies from transferring seized property to "any federal agency or any governmental entity not created under and subject to state law," absent a California court finding that one of the three enumerated conditions existed to justify the transfer: (1) it reasonably appeared that the activity giving rise to the investigation or seizure was interstate in nature and sufficiently complex to justify a transfer; (2) the seized property could only be forfeited under federal law, and not under state law; or (3) pursuing forfeiture under state law would unduly burden prosecuting attorneys or law enforcement agencies. ${ }^{255}$ Additionally, the proposal would have authorized state courts to refuse a petition for transfer "if the transfer would circumvent the protections of the California Constitution or this chapter that would otherwise be available to the property owner."256

Despite its clear implications for law enforcement agencies, SB 1866 somehow sailed through the Senate and Assembly committees without much debate. ${ }^{257}$ However, law enforcement groups caught up with the bill in its last weeks in the legislative process and lobbied Governor Davis to

251. Id.

252. A.B. $662 \S 10,1999-2000$ Reg. Sess. (Cal. 1999) (as amended Sept. 1, 1999).

253. Veto Message, A.B. 662, 1999-2000 Reg. Sess. (Cal. Sept. 28, 1999).

254. Complete Bill History, S.B. 1866, 1999-2000 Reg. Sess. (Cal. 2000), available at http://www.leginfo.ca.gov/pub/99-00/bill/sen/sb_1851-1900/sb_1866_bill_20001130_history.html (last visited May 1, 2002).

255. S.B. 1866, 1999-2000 Reg. Sess. (Cal. 2000) (as amended Apr. 6, 2000).

256. Id.

257. Karen Dillon, State Moves on Cash Seizures; California Offers Lesson on Forfeiture, Kansas CITY StAR, Sept. 3, 2000, at A1. 
veto the measure. ${ }^{258}$ The lobbying effort was successful, and Davis vetoed the measure on September $24,2000,{ }^{259}$ stating:

I do not believe that it is appropriate to require judges to interfere with the ability of California law enforcement officers' ability to make use of federal law provisions when they deem that it is appropriate to do so ... [or] to take away law enforcement's discretionary powers to make use of these laws. ${ }^{260}$

Davis's veto of both $A B 662$ and SB 1866 was not surprising given his reputation for being a friend of law enforcement groups. ${ }^{261}$ The fate of SB 1866 demonstrates both the political pull of the law enforcement lobby and its commitment to use political resources to preserve loopholes that maintain access to the financial rewards of civil asset forfeiture. Given the strength of the lobby's political weight, it is unlikely that any measures it strongly opposes will become law. However, there are still several ways federal adoption can be limited.

\section{Possibilities for Future Reform}

Should the proceeds of state civil asset forfeiture be redirected to the public schools, federal adoption and local ordinances will become even more desirable to law enforcement, as they will be the only way for law enforcement to benefit financially from civil asset forfeiture. However, this fact may be the key to successful passage of bills like $A B 662$ and $S B$ 1866. Specifically, a publicity campaign exposing the fact that federal adoption diverts money away from public schools could galvanize public support for a law restricting the use of the loopholes.

The experience of Missouri is instructive in this respect. The Missouri Constitution requires that proceeds from drug-related forfeitures go to public education. ${ }^{262}$ In 1999 , an audit revealed that $85 \%$ of drug-case forfeitures were going through the federal system and bypassing the Missouri constitutional allocation. ${ }^{263}$ In response, a Missouri State Senator sponsored a bill in 2001 that allows police to turn forfeiture proceeds over to a federal agency only after proving to a state court that the case is more appropriate for federal investigation. ${ }^{264}$ Missouri courts could approve transfers only if the underlying case "is reasonably likely to result in federal criminal

258. Id.

259. Complete Bill History, S.B. 1866, supra note 254.

260. Veto Message, S.B. 1866, 1999-2000 Reg. Sess. (Cal. Sep. 24, 2000).

261. Dillon, California Governor Vetoes Forfeiture Reform; Plan Would Make It Tougher for Police to Keep Drug Money, Kansas City Star, Sept. 28, 2000, at A5.

262. Mo. Const. art. IX, $\S 7$ (2001).

263. Steve Kraske, Drug Forfeiture Law Called a State Model, Kansas City StaR, July 18, 2001, at $\mathrm{A} 8$.

264. Karen Dillon, Holden Expected to Sign Bill Today to Reform Seizure Laws, Kansas CITY STAR, May 17, 2001, at Al [hereinafter Dillon, Holden Expected to Sign]. 
charges being filed, based upon a written statement of intent to prosecute from the United States attorney with jurisdiction." 265 Even before the measure was enacted, media attention and bad publicity, highlighting the fact that law enforcement agencies were using federal adoption to divert money away from education, made a difference: due to pressure from bad publicity, a Kansas City police chief announced that his department would begin following state law. ${ }^{266}$ Also, two Kansas City attorneys filed classaction suits to retrieve the money that was diverted from education by way of federal adoption, and a Missouri court ruled that the police were breaking the law by handing forfeitures to the federal government without a state court order. ${ }^{267}$ Although Missouri police and prosecutors staunchly opposed the bill, they were unable to overcome the widespread support for the bill, and Missouri Governor Bob Holden signed the measure into law on May $17,2001{ }^{268}$

Should California successfully reformulate its civil asset forfeiture distribution scheme to direct proceeds to public schools, the same public pressure can be employed to highlight law enforcement agencies' use of both federal adoption and local ordinances to keep civil asset forfeiture proceeds for themselves, contrary to state law. The same pressure may enable the passage of measures such as AB 662 and SB 1866 in spite of law enforcement objections, particularly in light of California's economic situation.

\section{CONCLUSION}

Civil asset forfeiture in the United States has evolved from a rarely employed legal fiction into the favorite weapon in the arsenal of law enforcement agencies. For all its constitutional implications, the fundamental defect of civil asset forfeiture is economic, not procedural. Procedural reform of the process, however progressive, will promote little actual change in the absence of a transformation of the financial incentives that motivate law enforcement groups to find and employ loopholes at the local and federal levels.

The economic distortions of civil asset forfeiture may be obvious, but solutions are less apparent and attempts to find and implement them have rarely been successful. California's experience with reform and circumvention suggests that law enforcement agencies may submit to procedural requirements, but they will employ their political capital to resist efforts to reduce the profitability of civil asset forfeiture. Reform efforts, therefore, must account for this political reality and begin by not only diverting civil

265. Mo. ANN. STAT. $\$ 513.647$ (2002).

266. Dillon, Holden Expected to Sign, supra note 264.

267. Id.

268. Id. 
asset forfeiture funds away from law enforcement, but also toward a group like education, which is both politically resourceful and distant from the implementation of the forfeiture process. Giving a worthwhile political competitor a stake in civil asset forfeiture will also strengthen future efforts to close loopholes and eliminate circumvention. California was once a leader in civil asset forfeiture reform, and its current unique economic and political circumstances make the state a suitable candidate for the kind of incremental reform proposed in this Comment-reform that addresses the root of the problem with civil asset forfeiture. 
